\title{
Article
}

\section{Digital Folklore of Rural Tourism in Poland}

\author{
Karol Król * a and Józef Hernik
}

Citation: Król, K.; Hernik, J. Digital Folklore of Rural Tourism in Poland. Sustainability 2022, 14, 1165. https:// doi.org/10.3390/su14031165

Academic Editors: Daniele Ferdani, Alfonsina Pagano and

Patrizia Schettino

Received: 29 December 2021

Accepted: 18 January 2022

Published: 20 January 2022

Publisher's Note: MDPI stays neutral with regard to jurisdictional claims in published maps and institutional affiliations.

Copyright: (c) 2022 by the authors. Licensee MDPI, Basel, Switzerland. This article is an open access article distributed under the terms and conditions of the Creative Commons Attribution (CC BY) license (https:// creativecommons.org/licenses/by/ $4.0 /)$.
Digital Cultural Heritage Laboratory, Department of Land Management and Landscape Architecture, Faculty of Environmental Engineering and Land Surveying, University of Agriculture in Krakow, Balicka 253c, 30-198 Krakow, Poland; rmhernik@cyf-kr.edu.pl

* Correspondence: k.krol@onet.com.pl

\begin{abstract}
Numerous development techniques and attributes that define the unique essentiality of archaic rural tourism websites in Poland have been identified. However, the use of e-folklore graphics on the websites heretofore has not been analysed. The paper's objective is to identify forms of digital folklore found on archaic websites of rural tourism facilities functioning in Poland from 2000 to 2015. The analysed sample was 185 websites stored in the Internet Archive. The focal points were the dynamics of content presentation and the type of graphic components, including marquee text containers and GIFs. The use of characteristic graphics and digital stamps was recorded as well. The results fuel a discussion concerning potential reasons for deleting copies stored in digital archives. It is further concluded that all digital copies, even those far from being complete or perfect, contribute to the integrity of the digital ecosystem as a whole. Therefore, the process of archiving Internet content must not be exclusive. Therefore, any actions towards preserving the digital ecosystem for further investigation are reasonable.
\end{abstract}

Keywords: cyberfolklore; e-folklore; virtual folklore; digital folklore; Internet folklore; virtual emanations of folklore; promotion of rural tourism; agritourism

\section{Introduction}

Not so long ago, the backbone of rural tourism marketing in Poland was websites built at the lowest possible cost and hosted on free servers [1]. The fact that the websites were developed by the farms (household members, friends) and were nonprofessional is relevant. Many were unique and considered Polish rural digital heritage [2]. They were most often developed with archaic techniques, floating frames (iframe) or tables. Their creators employed scrolling text in marquee containers, and the 900 px wide viewport was typical of 15" CRT monitors [1]. Still, the exceptionality and general design of such websites stemmed mainly from digital folklore elements.

According to the literature, digital folklore is often special and highly diversified. It also achieves unprecedented reach and availability. It has never been so easy to become an architect of (digital) folklore; any device with access to the Internet is sufficient. In a way, this process realises the technological 'community' [3].

Numerous attributes that defined the unique essentiality of archaic rural tourism websites in Poland have been identified. The research concentrated on development techniques and HTML code exploration [1,2]. However, the use of digital folklore graphics on the websites is yet to be analysed. A question arises whether such elements had been used in archaic websites of rural tourism facilities in Poland. The paper's objective is to identify forms of digital folklore found on archaic websites of rural tourism facilities in Poland. A hypothesis emerges from the research to date $[1,2]$ that websites of rural tourism facilities hosted on free servers have elements of digital folklore due to the development techniques. Our contributions in this paper are summarised as follows:

- The research involved a unique set of copies of archaic websites of rural tourism facilities in Poland found in digital archives. 
- A typology of rural tourism digital folklore components was proposed.

- The authors identified and presented components of digital folklore characteristic of archaic websites of rural tourism facilities in Poland.

This paper is organised into six sections. Section 2 follows the introduction and sheds light on selected concepts relevant to promoting rural tourism in Poland online, focusing on free hosting. It also defines digital cultural heritage and depicts folklore as local traditions of commoners, followed by its digital counterparts. Section 3 presents the research methodology with the typology of graphics that were investigated. Section 4 focuses on the results. It presents the profile of the identified graphics, the frequency of digital artefacts, and rustic elements of digital folklore. Section 5 discusses the findings and initiates a venture into the possible reasons for (irreversible) deletion of digital copies. The final section is conclusions and limitations, and further research.

\section{Background}

Websites are most often used by the business to inform, win new customers, build relationships, and foster user community [4]. Rural enterprises are no different in this regard [5]. According to a survey by IAB Poland and PwC aimed at defining the importance of the Internet for Polish enterprises, online sales was the most popular among the automotive, tourism, and logistic industries. Interestingly, the report emphasised the progress towards online sales among rural entrepreneurs. About $41 \%$ of them sold their products and services via their personal website, auction sites, and/or e-commerce platforms [6]. One subset of this group is rural tourism facilities, that is, places in rural areas, including agritourism farms, that offer tourism services, such as rooms, houses, and summer cabins for rent, catering, and others. Such facilities present their offers on their websites, thematic portals, and social media $[7,8]$.

The online presentation of tourism offer evolves with ICT as all businesses with online presence try to follow the change, owners of rural tourism facilities included $[5,9,10]$. However, it can be expensive to upgrade a website or replace it with a new one, a cost not negligible for small businesses. Therefore, owners of tourism facilities in Poland were keen on free hosting from 2000 to 2015 [1]. They used free servers to publish websites they built themselves. They were usually nonprofessional, static sites with basic contact data. Free URLs of such websites (mainly in a subdomain) were posted in free web directories and vertical portals (Figure 1). Proprietary e-commerce platforms or social media were used much less frequently. Even though it was difficult to evaluate the performance of such promotion, it was a prevalent approach [1].

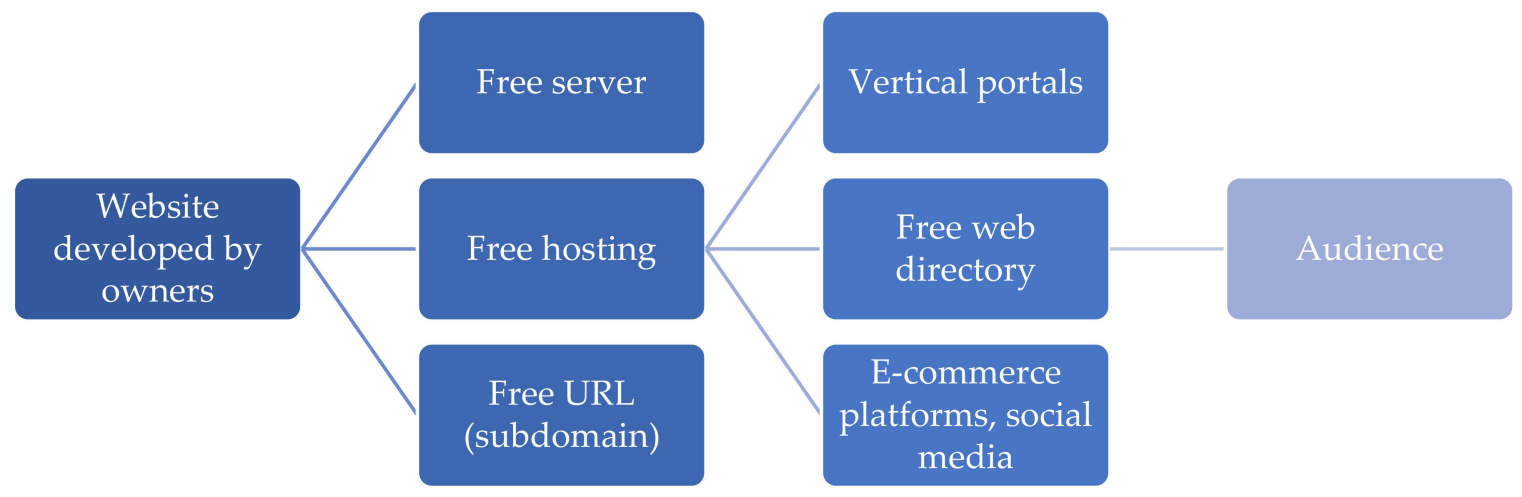

Figure 1. Diagrammatic visualisation of rural tourism facilities promotion in Poland using free hosting; most popular in Poland from 2000 to 2015.

The popularity of free hosting and nonprofessional websites was mainly due to the nature of the tourism business in rural Poland. Agritourism used to be mostly a side job for extra profit [11]. This affected the approach towards promotion. The owners did not have the money, did not want to invest it, or did not know how to invest it in marketing. 
Still, the development of tourism in rural areas enticed owners of tourism facilities to pay more heed to online promotion $[8,12]$. At the same time, the effectiveness of their current approach declined due to technological change. It became unreasonable to continue using free hosting and archaic websites. As a consequence, owners of agritourism farms started replacing their old websites with new ones. Unique, archaic websites of rural tourism facilities vanished from search results in the wake of the discontinuation of web directories and free hosting. They are now investigated by Internet archaeologists who analyse their cultural impact as historical artefacts [1].

\subsection{Digital Cultural Heritage}

Cultural heritage consists of places, physical objects, and intangible assets of cultural, historical, aesthetic, archaeological, scientific, ethnological, or anthropological value for groups or individuals. Tangible cultural heritage encompasses material artefacts created, maintained, and handed down through generations by members of various communities. It includes works of art, buildings, structures and statues, and other material or tangible products of human creativity that are culturally relevant [13].

The perception of cultural heritage has been evolving in Poland and worldwide in recent years. Cultural heritage assets are no longer restricted to monuments that are expensive to maintain and fail to conform to developmental challenges. Cultural heritage has become a stimulus for socioeconomic growth, a component of products and services, and an important part of identity and image. Moreover, it is now considered fuel for social capital relevant to preserving social integrity and preventing exclusion [14]. Cultural heritage assets, tangible, intangible, and environmental, now determine the tourist, recreational, and developmental value of its surroundings. It has become the best interest of local communities to improve the quality of historic sites and use them to drive the economic development of their region [15].

At first, only selected tangible assets of national culture and environmental components were considered important: physical, biological, and geological features; habitats of plants or animal species, and areas of value in scientific, aesthetic, or conservation terms [16]. The set of objects considered worthy of interest gradually grew as urban and rural features, cultural landscapes, the heritage of ethnic and religious minorities, and works of recent times were added to it $[17,18]$. The scope of cultural heritage expanded to include works of applied art and industrial and technical objects. Today, heritage also encompasses intangible values, such as customs and rituals, traditional production, agriculture, and artistic activities, historical functions of sites, and their symbolism [14]. Intangible cultural heritage is traditions passed down the generations, stories and anecdotes, plays, music, songs and dance, creation of puppets and theatre, festivals, knowledge and practices related to nature and the universe, such as folk medicine or folk astronomy [19]. Nevertheless, the classic perception of heritage had to be revised as new information and communications technologies emerged. The process yielded a new category, digital heritage, responding to technological change.

The literature offers a broad array of digital cultural heritage assets. They can be categorised into digitalised objects, metadata, and born-digital content [20]. Digital heritage covers human knowledge and expression, including cultural, educational, scientific, and administrative resources and technical, legal, medical, and others, born-digital or digitised from analogue forms. Digital artefacts come as texts, databases, still and moving pictures, sounds, graphics, software, websites, and others [2].

Digital artefacts exhibit at least two particular features: they can be copied and reconstructed countless times, but at the same time, it is easy to lose them irreversibly. The years-long history of personal computers and software is already at risk of loss of countless heritage assets due to hardware redundancy and dynamic development of software, lack of expert knowledge, and legal problems, including intellectual property protection [21].

Digital technologies have increasing applications. New, unprecedented forms of communication and expression emerge that quickly replace the previous ones. Digital artefacts 
come in virtually all languages, from all parts of the world, and every domain of human activity. As a consequence, the availability of digital data has become a global problem not only for digitised museums' collections, libraries, and archives but also software, computer graphics, design components, netnography, storytelling, and digital folklore. Many of these assets represent significant cultural value. Hence, it is part of the heritage to be preserved for current and future generations [22]. Digital folklore belongs to this category [23].

\subsection{Traditional and Digital Folklore}

\subsubsection{Folklore-The Knowledge of the People}

The term 'folklore' was coined by a British writer William Thoms in 1846, who used it to denote the oldest components of culture, such as old customs, rites, superstitions, ballads, tales, legends, songs, and proverbs. Folklore is perceived as associated with the 'common people' but in the broader context, it encompasses works of members of a community with a specific cultural identity [24,25]. Folklore is believed to be an emanation of authentic local and regional culture. Works of folklore are part of cultural heritage and are protected just as tangible cultural monuments through surveys, conservation, and popularisation.

In Poland and other European countries, the interest in folklore is fuelled mostly by historical conditions. Glorification of the simple commoner is associated with the beauty and diversity of folk behaviours and customs, which were believed to be endangered, and thus worthy of recording and preserving for future generations back in the eighteenth century. The core of the Polish culture of the twentieth century was a peasant and minor gentry culture founded on traditional local bonds. High culture was represented mainly by aristocrats, church hierarchs, the learned, artists, and wealthy burghers. Until the twentieth century, working-class and peasant folklore was considered part of proletarian traditions of urban and rural areas that invigorated different regions [24,26].

Dynamic cultural changes gave rise to the acknowledgement of different types of folklore, which quickly integrated with popular culture and was no longer 'owned' by a single group [27]. Traditional folklore is associated mainly with oral art and characterised by face-to-face communication, mostly within small, local communities. It is local in nature, which greatly impacts group identity. In this context, folklore cements and anchors local communities in time and place and emphasises intellectual and mental community.

Folklore traditions used to be circulated by local narrators, songsters and musicians, itinerant bards and shamans. The Internet lacks the potential for folklore generation in the traditional sense. Digital folklore knows no spatial, cultural, or ethnic boundaries [26,28]. Today, when the online audience is potentially unlimited, every member can be a creator and sender of the message. The raconteur and audience are separated by technology, which makes the act of sending and receiving isolated and asynchronous [29].

\subsubsection{Digital Folklore}

Although the phenomenon of digital folklore has been investigated for quite some time (it is also referred to as Internet folklore, netlore, e-folklore, network folklore, folknet, virtual folklore, etc.), the notion was first coined by O. Lialin and D. Espenschied in 2009. They found out that digital folklore is an audience culture that emerged from programmes and services focused on the user-creator: 'Digital folklore includes customs, traditions, and elements of visual, textual, and audio culture that arose as a result of users' interaction with programs installed on their personal computers during the last decade of the twentieth century and the first decade of the twenty-first' [23] (pp. 9-10). E-folklore covers behaviour, customs, and visual/graphic, text, and sound elements co-created by users of digital devices day by day worldwide in the last two decades of the twentieth century and in the early twenty-first century [30].

Although graphics created by users, such as flashing arrows, blinking stars, photographs of animals, colourful icons, trims and lights, jumping puppet clowns, and rainbow gradients are kitsch today, they used to be universally popular on websites. Over the last four decades, this sort of semiotic resources and user practices has been approached from 
multiple angles: as forms of textual play, as examples of visual or linguistic creativity, as a material culture resulting from networked communications, as vernacular resources for identity-making, and as the folk art of new media [31]. The flow of time and technology change resulted in selected phenomena, forms of communication and expression, and graphics being considered examples of e-folklore [25,32].

Digital folklore is represented by various folkloristic forms, found mostly on the Internet [30]. A review of the key modern-day works demonstrates that e-folklore is syncretic, as seen in the diversity of folkloristic word-visual artefacts [23,33]. Digital folklore is diversified, sometimes complicated, and dynamic, which is an additional obstacle for research and typological attempts. At the same time, it can be consistent with some traditional folklore genres that have accommodated the conditions in the digital ecosystem. Legends, anecdotes, rhymes, proverbs, and similar creations undergo substantial transformations in the Internet's verbal, functional, and semantic domains. This saves them from becoming obsolete and bestows the status of popular e-folklore genres. It is not the same for graphics, which may sometimes be considered outdated or treated as 'digital junk' [30].

New technologies favour mainly the proliferation of visual folklore. The process is driven by the increase in smart mobile device users who have access to the Internet and software. Users can take advantage of various formats of computer graphics and visualisations, from static rasters to dynamic ones and multimedia. Internet folklore includes elements of so-called cybermythology and communication codes, such as specific Internet slang or characteristic communications behaviour [34]. Digital folklore encompasses various works of users, including jokes, memes, various compilations of graphics and texts, including special signs and pictograms, but also anecdotes, legends, blog posts, etc. [30]. The variety of forms of digital folklore grows exponentially. The objects can rapidly change the target group and skulk on various websites [26]. They can provide valuable insight into technology change and socioeconomic or cultural development $[35,36]$.

\section{Materials and Methods}

The analysed sample was 185 websites of rural tourism facilities in Poland stored in the Internet Archive (IA). Rural tourism facilities are places in rural areas, including agritourism farms, that offer tourism services, such as rooms, houses, and summer cabins for rent, catering, and others. The survey was conducted in December 2021.

The study involved nonprofessional websites hosted on free servers and with free URLs. Their addresses were fetched from web directories of Onet (katalog.onet.pl) and Wirtualna Polska (katalog.wp.pl) before they were discontinued. Most of the copies come from 2001 to 2005 . They constitute about $62 \%$ of the studied sample (59 websites). The investigated sample consisted of 35\% of copies from 2006 to 2010 (33 websites) and three website copies from 2012 to 2013 (about 3\%).

The in-depth analysis focused on graphic layouts of the websites. The exploratory research focused on the dynamics of content presentation and type of graphic components (born-digital objects), including marquee text containers and GIFs. Static websites are defined as those with no moving components. Missing content and presence of special objects, digital stamps were noted as well. Based on previous studies [1,2], and the literature review, graphic elements of e-folklore have been categorised as marquee components, digital trims, ready-made digital components, digital stamps, rustic components of digital folklore, and pictograms. The results are presented quantitatively and as case studies.

Marquee components were most often a text scrolling horizontally or vertically within a text box. They were generated with the $<$ marquee $>$ tag that animated text or graphics. Digital trims are images of horizontal decorative patterns. Ready-made digital components are graphic elements used to build the website, usually in the Web 1.0 era. These were rounded corners, backgrounds, or impressive buttons. They were combined on the screen and provided a background for other text or graphic components. Today, many such effects are achieved with cascading style sheets (CSS). Digital stamps are website components characteristic of a specific period, circumstances, or website development technique. They 
can often be used to determine the era when the website originated or the technique with which it was built. Rustic components of digital folklore are rustic decorative elements inspired by work and life in the countryside. Eventually, pictograms are signs that convey meaning with symbols. They are universal and widely used even today. It is not the case for 'rectangular icons' that were the core of link exchange and were usually inserted in the page footer. They originated from icons confirming syntactic correctness according to W3C and PageRank icons and are rarely used today.

\section{Results}

Static websites amounted to about $83 \%$ of the sample. Among them were 13 text websites without any graphics (about $7 \%$ ). Data were missing completely or partially for $73 \%$ of the websites. The copies in the digital archives were mostly missing graphic elements (Table 1). Graphic and/or textual attributes that indicated the archaic nature of the websites were identified in $51 \%$ of them (95).

Table 1. Quantitative statistics of selected development attributes.

\begin{tabular}{cccc}
\hline Development Attributes & No Graphics; Text Website & $\begin{array}{c}\text { No Animated Graphics; } \\
\text { Static Website }\end{array}$ & No Data; Content Lost \\
\hline Number of websites & 13 & 154 & 136 \\
\hline Percentage & 7.03 & 83.24 & 73.51 \\
\hline
\end{tabular}

The special character of digital folklore assets emerges first and foremost from the context and the way they were used. Animated graphics were relatively rare. On the contrary, the websites' structures were extraordinarily simple, with merely a few hypertextual elements (Table 2). The sites consisted mostly of basic HTML tags, such as $<\mathrm{td}>$ (tables), $<$ img $>$ (graphics), $<$ a $>$ (hyperlinks), $<$ span $>,<$ font $>$, and bulleted lists $(<\mathrm{li}>)$.

Table 2. The profiles of graphic elements found on the websites.

\begin{tabular}{ccccc}
\hline Development Attributes & $\begin{array}{c}\text { Dynamic Marquee Text } \\
\text { Containers }\end{array}$ & Graphics: GIF & Static Elements & Dynamic Elements \\
\hline Number of websites & 21 & 81 & 68 & 37 \\
\hline Percentage & 11.35 & 43.78 & 36.76 & 20.00 \\
\hline
\end{tabular}

The sample included several basic categories of digital artefacts. They are no longer used or very rare. For example, users are not informed today about the suggested screen resolution to best view the content because websites change to fit the display (responsiveness). No static, manually typed update dates in the footer are used nowadays. Marquee containers, SMS gateways, static visitor counters, splash screens, or guestbooks are not featured on websites anymore (Table 3). Ready-made digital components are also rarely used.

Table 3. Frequency of digital artefacts.

\begin{tabular}{cccccc}
\hline $\begin{array}{c}\text { Development } \\
\text { Attributes }\end{array}$ & $\begin{array}{c}\text { Digital Trims; Separating } \\
\text { Dashed Lines }\end{array}$ & $\begin{array}{c}\text { Ready-Made Digital } \\
\text { Components }\end{array}$ & Digital Stamps & $\begin{array}{c}\text { Rustic Elements of } \\
\text { Digital Folklore }\end{array}$ & $\begin{array}{c}\text { Pictograms } \\
\text { Number of websites }\end{array}$ \\
\hline Percentage & 4 & 27 & 10 & 7 & 5 \\
\hline
\end{tabular}

The sample had many digital artefacts but not many rustic elements of cyberfolklore. These were rustic graphics, static or animated (Figure 2) or graphics stylised as farm or ranch equipment and representations of fauna and flora. They were rare in the sample. Those identified were most often isolated components to accompany the text. 

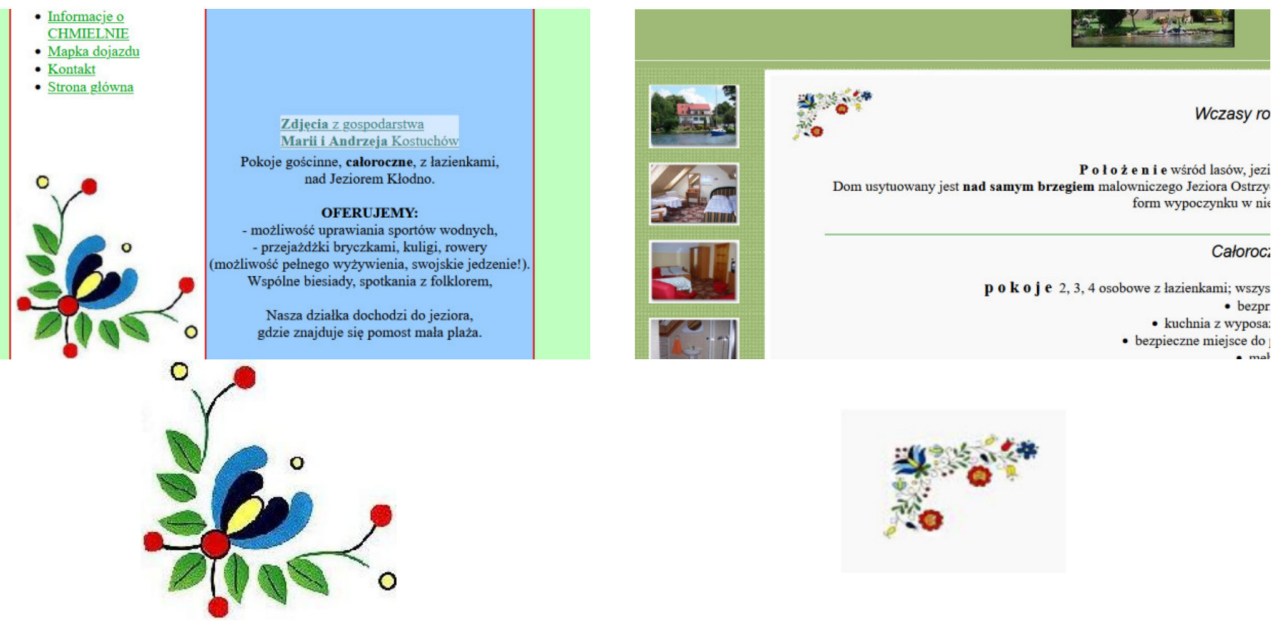

Figure 2. Rustic elements of cyberfolklore. Left to right: graphics from the website of makostuch.fm.interia.pl (a copy from 2003) and nabrzegu.republika.pl (a copy from 2012). Source: Internet Archive.

Some websites of rural tourism facilities used static and animated GIFs. Their primary roles were website navigation and reinforcement of the written message. In such cases, they were images of post boxes, arrows, or pictograms (Figure 3). They were usually brightly coloured to improve the appeal of the website and draw the user's attention to selected content or functionality, such as the guestbook or contact data. Other graphics were just additions and were much less popular. The number of rustic elements was even smaller.

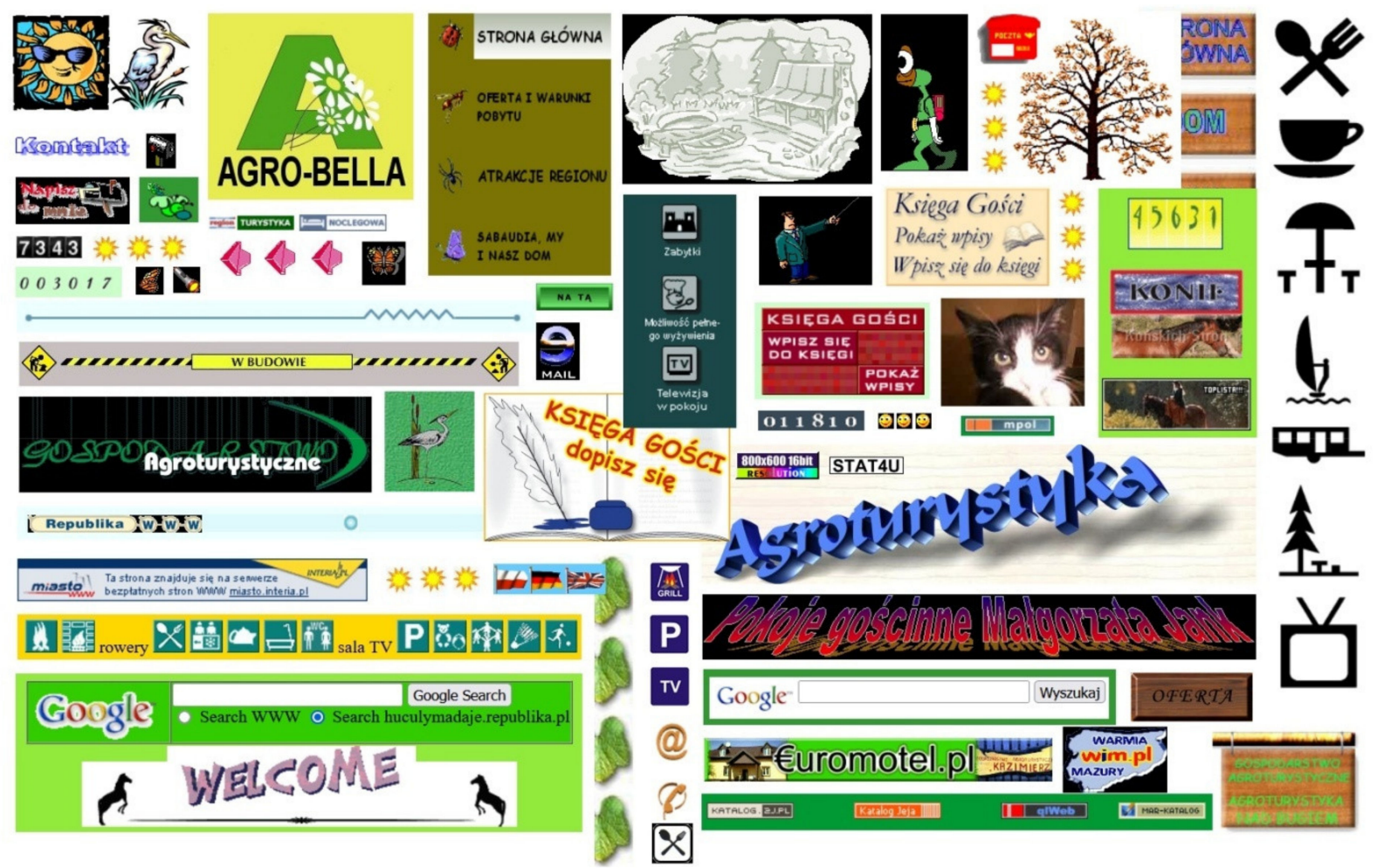

Figure 3. A collage of graphics found on websites of rural tourism facilities in Poland. Source: Internet Archive.

Two groups of special elements were identified among graphics on archaic websites of rural tourism in Poland: pictograms and icons characteristic of Web 1.0 (Figure 4). In most 
cases, they were links to web directories under a link exchange scheme. The website owner could list it in a web directory free of charge but had to link to the directory in return.

\begin{tabular}{|c|c|c|c|c|c|c|c|}
\hline MAR & PROMOCJA & KCS KATALOE & KATALOGSTPONB & \begin{tabular}{|l|l|} 
WEB SEO FRIENDLY \\
\end{tabular} & \begin{tabular}{|l|} 
KATALOGSTRON \\
\end{tabular} & WWYZUKAJ & \begin{tabular}{|l|l|} 
K1 & KATALOG
\end{tabular} \\
\hline
\end{tabular}

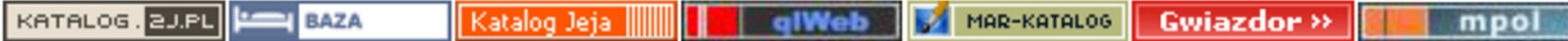

Figure 4. Icons used in website footers as part of link exchange. Source: Internet Archive.

The other element characteristic of archaic websites of rural tourism facilities in Poland is pictograms. They are graphics that inform about details of tourism offered in a universal manner (Figure 5).

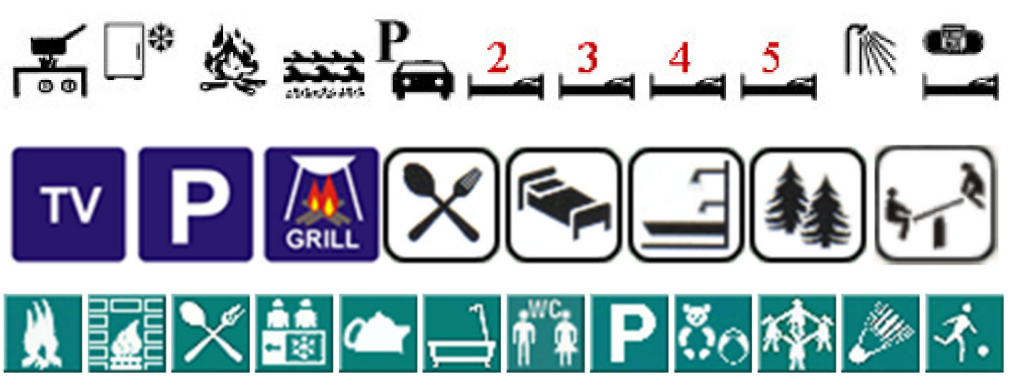

Figure 5. Pictograms with information about offer details. Source: Internet Archive.

\section{Discussion}

In the time of Web 1.0 and Web 2.0, it was common to confirm website quality with a 'validation icon' or PageRank. Websites that were developed flawlessly and passed code validation with the W3C Markup Validation Service could display an icon that functioned as a certificate. It confirmed that the website development technique conformed to the World Wide Web Consortium standards. These icons gained popularity and were used by many service providers. Today, they can be used as 'digital stamps' with which a website can be dated, i.e., the time when it was developed can be determined.

The characteristic feature of Polish rural tourism websites is a classic, rustic design. It was confirmed in a study on the graphic design of 282 websites of agritourism farms [37]. It involved websites with the .pl country code top-level domain. The author verified such modern design concepts as one-page design, long-page design, flat design, and material design. The sample had 102 (36\%) websites that followed old design principles, including 'narrow layout' and small font size from 9 to 11px, typical of 15" CRT monitors. The websites were static and included poor-quality graphics. Most websites in the sample have been demonstrated to be developed following classic, conservative principles according to 2008-2012 standards.

The study showed that in the time of Web 1.0, animated GIFs were more popular on private, hobby, social, or personal info websites that were often infantile [28,32,38]. On the other hand, the investigated websites represented businesses, which suggests they were more official, even though the techniques were nonprofessional and the sites were published on free servers. However, it was not uncommon from 2000 to 2015, when even public institutions, such as schools, kept their websites on free servers of Republika WWW and Miasto WWW [2].

The investigated websites were nonprofessional. Paradoxically, this characteristic contributed to their uniqueness in many cases. Most of them were static. The only dynamic components were animated GIFs. Many elements were missing. Digital archives preserved mostly text. Many images are unavailable, leaving shreds, ripped scaffoldings for graphics. Many of them are so incomplete that they can be considered digital junk. Moreover, the awareness of these assets is also dwindling gradually. The average Internet user may not know about archaic directories and free hosting in Poland in a few years. They could no 
longer be sought and needed. This leads to the question of whether it is justified to store such copies. Even though incomplete copies do not take up much server storage, their sheer volume can have a significant impact. Is the completeness of a digital copy the attribute decisive for its preservation? It is reasonable to store incomplete copies of nonprofessional, archaic websites of rural tourism facilities in Poland? The questions remain open.

\section{Conclusions}

The paper presents results of exploratory research on 185 websites of rural tourism facilities in Poland stored in the Internet Archive. The analysis covered the oldest copies of archaic websites hosted on free servers with free URLs. The copies were analysed in terms of digital artefacts, including animated graphics and elements of cyberfolklore.

Most investigated websites were static. Many archived copies were incomplete, which could affect the results. What makes the websites special and archaic are the development technique and graphics. Some components of the websites such as marquee animations, visitor counters, guestbooks, or animated GIFs, are 'digital time stamps'. Still, the archaism of a given component is not due to its type (kind) but the way it has been developed, used, and presented. Today, some websites have marquee-like components, which conform to current standards. Many archaic components, such as traditional guestbooks, have been replaced with comment systems and social media. The way objects are presented has evolved as well. They are dynamically adapted to the screen of the terminal. Therefore, digital artefacts can be classified, but their archaism is due to the type of the object and how it was created and presented. The function (the way it worked) matters as well.

The investigated sample contained few rustic elements of digital folklore, such as 'digital trimming', rural objects, natural features, plants, or animals. More popular, even though still rare, were websites stylised as ranches with 'wooden' graphics.

Digital copies of websites are 'images frozen in time'. An irreversible deletion of a component, for example, due to the incompleteness of a digital copy, will create a gap in the resources, leading to link rot intensification. All digital copies, even incomplete and imperfect ones, contribute to the 'integrity, coherence of the digital snapshot'. Therefore, the process of archiving Internet content should not be exclusive. Any actions towards preserving the entire digital ecosystem for further investigation are reasonable.

\section{Limitations and Further Research}

The study's primary limitation was missing images in digital archives. This state of affairs affects conclusions because had the websites been complete, components of digital folklore could have been much more prevalent. At first glance, incomplete copies of websites are Internet junk, but texts, such as price lists and descriptions of tourism offers, were preserved in most cases. They can be investigated further as records of socioeconomic change in rural areas.

Author Contributions: Conceptualisation, K.K.; methodology, K.K.; software, K.K.; validation, K.K.; formal analysis, K.K.; investigation, K.K.; resources, K.K.; data curation, K.K.; writing—original draft preparation, K.K.; writing—review and editing, K.K.; visualisation, K.K.; supervision, K.K. and J.H.; project administration, K.K.; funding acquisition, J.H. All authors have read and agreed to the published version of the manuscript.

Funding: This study was financed by the Ministry of Science and Higher Education of the Republic of Poland under the project "Cultural heritage of small homelands" (No. PPI/APM/2018/1/00010/U/001) financed by the Polish National Agency for Academic Exchange as part of the International Academic Partnerships.

Institutional Review Board Statement: Not applicable.

Informed Consent Statement: Not applicable.

Data Availability Statement: All trademarks and registered trademarks mentioned herein are the property of their respective owners. The company and product names used in this document are 
for identification purposes only. The source of the figures: Internet Archive (https://archive.org/, accessed on 16 December 2021). Access to the Internet Archive's Collections is provided at no cost and is granted for scholarship and research purposes only.

Acknowledgments: The author wishes to express his gratitude to the reviewers for their constructive criticism, which contributed to the final content of the paper. The paper was written at the Digital Cultural Heritage Laboratory (https: / / culturalheritage.urk.edu.pl accessed on 11 January 2022) part of the Department of Land Management and Landscape Architecture at the Faculty of Environmental Engineering and Land Surveying of the University of Agriculture in Krakow, Poland. The research was carried out as part of the scientific project entitled Digital cultural heritage of rural areas $(2021 / 05 /$ X/HS3/00859) financed by the National Science Center Poland.

Conflicts of Interest: The authors declare no conflict of interest. The funders had no role in the design of the study; in the collection, analyses, or interpretation of data; in the writing of the manuscript, or in the decision to publish the results.

\section{References}

1. Król, K. Forgotten agritourism: Abandoned websites in the promotion of rural tourism in Poland. J. Hosp. Tour. Technol. 2019, 10, 431-442. [CrossRef]

2. Król, K. Digital cultural heritage of rural tourism facilities in Poland. J. Cult. Herit. Manag. Sustain. Dev. 2020, 11, 488-498. [CrossRef]

3. Przeklasa, S. Chorwacki folklor internetowy: Geneza, definicje, przykłady. Stud. Zesz. Nauk. Inst. Filol. Słowiańskiej UJ 2017, 1, 69-87.

4. Hernández, B.; Jiménez, J.; Martín, M.J. Key website factors in e-business strategy. Int. J. Inf. Manag. 2009, 29, 362-371. [CrossRef]

5. Ammirato, S. An Empirical Study of Agritourism Evolution and E-Commerce Adoption Challenges. Inf. Technol. Tour. 2010, 12, 89-104. [CrossRef]

6. Głąb, A. Rynek Biznesowy. In Raport IAB: Wpływ Internetu na Gospodarkę w Polsce; Związek Pracodawców Branży Internetowej: Warszawa, Polska, 2014; pp. 10-12. Available online: https://www.iab.org.pl/wp-content/uploads/2014/11/wplyw_internetu_ na_gospodarke_raport_iab_polska.pdf (accessed on 11 January 2022).

7. Platania, M. Agritourism farms and the web. An exploratory evaluation of their websites. Agris -Line Pap. Econ. Inform. 2014, 6, 51-58.

8. Gössling, S.; Lane, B. Rural tourism and the development of Internet-based accommodation booking platforms: A study in the advantages, dangers and implications of innovation. J. Sustain. Tour. 2015, 23, 1386-1403. [CrossRef]

9. Sanders, J.; Galloway, L. Rural small firms' website quality in transition and market economies. J. Small Bus. Enterp. Dev. 2013, 20, 788-806. [CrossRef]

10. Zopounidis, C.; Lemonakis, C.; Andreopoulou, Z.; Koliouska, K. Agrotourism Industry Development through Internet Technologies: A Multicriteria Approach. J. Euromarketing 2014, 23, 45-67. [CrossRef]

11. Jęczmyk, A.; Uglis, J.; Graja-Zwolińska, S.; Maćkowiak, M.; Spychała, A.; Sikora, J. Research Note: Economic Benefits of Agritourism Development in Poland-An Empirical Study. Tour. Econ. 2015, 21, 1120-1126. [CrossRef]

12. Bajgier-Kowalska, M.; Tracz, M.; Uliszak, R. Modeling the state of agritourism in the Malopolska region of Poland. Tour. Geogr. 2017, 19, 502-524. [CrossRef]

13. UNESCO. Charter on the Preservation of Digital Heritage. 2003. Available online: http://bit.ly/unesco-digital (accessed on 11 January 2022).

14. Murzyn-Kupisz, M. Podmioty na rynku dziedzictwa kulturowego. Studia Reg. Lokalne 2010, 3, 61-80.

15. Bowitz, E.; Ibenholt, K. Economic impacts of cultural heritage-Research and perspectives. J. Cult. Herit. 2009, 10, 1-8. [CrossRef]

16. UNESCO. Convention for the Safeguarding of the Intangible Cultural Heritage; UNESCO: Paris, France, 2003.

17. Aplin, G. World Heritage Cultural Landscapes. Int. J. Herit. Stud. 2007, 13, 427-446. [CrossRef]

18. Agnoletti, M. Rural landscape, nature conservation and culture: Some notes on research trends and management approaches from a (southern) European perspective. Landsc. Urban Plan. 2014, 126, 66-73. [CrossRef]

19. Kurin, R. Safeguarding Intangible Cultural Heritage in the 2003 UNESCO Convention: A critical appraisal. Mus. Int. 2004, 56, 66-77. [CrossRef]

20. Navarrete, T. Digital cultural heritage. In Handbook on the Economics of Cultural Heritage; Rizzo, I., Mignosa, A., Eds.; Edward Elgar: Cheltenham, UK, 2013; pp. 251-271.

21. Heinonen, M.; Reunanen, M. Preserving our digital heritage: Experiences from the Pelikonepeijoonit project. In History of Nordic Computing 2; Impagliazzo, J., Järvi, T., Paju, P., Eds.; Springer: Berlin/Heidelberg, Germany, 2009; pp. 55-64. [CrossRef]

22. Jeffrey, S. A new Digital Dark Age? Collaborative web tools, social media and long-term preservation. World Archaeol. 2012, 44, 553-570. [CrossRef]

23. Lialina, O.; Espenschied, D. Digital Folklore: To Computer Users, with Love and Respect; Merz Akademie: Stuttgart, Germany, 2009.

24. Krawczyk-Wasilewska, V. E-folklor jako zjawisko kultury digitalnej. Transformacje 2009, 58-63, $220-228$.

25. Krawczyk-Wasilewska, V. Folklorystyka online w świetle problematyki dziedzictwa digitalnego. Zesz. Wiej. 2016, 22, 69-76. 
26. Krawczyk-Wasilewska, V. Tradycja lokalna czy kultura globalna? Dylematy badacza folkloru polskiego. In Folklór a Folkloristika vo Svete Postmoderny; Profantova, Z., Ed.; Zing Print: Bratislava, Slovenská, 2013; pp. 31-46.

27. Pomieciński, A.; Burszta, J. E-folklor: Wstęp. Kult. Pop. 2012, 3, 4-5.

28. Krawczyk-Wasilewska, V. E-Folklore in the Age of Globalization. Fabula 2006, 47, 248-254. [CrossRef]

29. Zdrodowska, M. E-, cyber-folklor. Nowy paradygmat badania nowych mediów? Kult. Pop. 2012, 33, $20-31$.

30. Melnikova, O.K.; Yahin, M.A.; Burenkova, O.M.; Makayev, K.F.; Makayeva, G.Z. Internet communication: Architecture and typology of digital folklore. IOP Conf. Ser. Mater. Sci. Eng. 2020, 890, 012212. [CrossRef]

31. De Seta, G. Digital folklore. In Second International Handbook of Internet Research; Hunsinger, J., Allen, M.M., Klastrup, L., Eds.; Springer: Dordrecht, The Netherlands, 2020; pp. 167-183.

32. Järv, R. Estonian Folklore Archives. Oral Tradit. 2013, 28, 291-298. [CrossRef]

33. Vargha, K. Creativity and Humor in the Online Folklore of the 2014 Elections in Hungary. Folk. -Electron. J. Folk. 2018, 74, 7-24. [CrossRef]

34. Derda-Nowakowski, M. Komunikacja społeczna w Internecie. Problemy badawcze. In Oblicza Komunikacji 1. Perspektywy Badań Nad Tekstem, Dyskursem i Komunikacja, t. 2, Red; Kamińska-Szmaj, I., Piekota, T., Zaśko-Zielińska, M., Eds.; Tertium: Kraków, Poland, 2006.

35. Lourdi, I.; Papatheodorou, C. A metadata application profile for collection-level description of digital folklore resources. In Proceedings of the 15th International Workshop on Database and Expert Systems Applications, Zaragoza, Spain, 3 September 2004; pp. 90-94. [CrossRef]

36. Lourdi, I.; Papatheodorou, C.; Nikolaidou, M. A multi-layer metadata schema for digital folklore collections. J. Inf. Sci. 2007, 33, 197-213. [CrossRef]

37. Król, K. Trendy projektowe w prezentacji gospodarstw agroturystycznych w Internecie. Tur. Rozw. Reg. 2017, 7, 37-47. [CrossRef]

38. Jensen Schau, H.; Gilly, M.C. We are what we post? Self-presentation in personal web space. J. Consum. Res. 2003, 30, 385-404. [CrossRef] 